\title{
ANALISIS KESALAHAN MAHASISWA DALAM MENYELESAIKAN SOAL CERITA TURUNAN PARSIAL
}

\author{
Elisa Novalinda Mata Ratu*, Siprianus S. Garak, Damianus D. Samo \\ ${ }^{1}$ Mahasiswa Pendidikan Matematika Universitas Nusa Cendana, ${ }^{2,3}$ Universitas Nusa Cendana \\ *mataratunova@gmail.com
}

Diterima: 05 Juni 2020 Disetujui: 29 Juli 2020 Dipublikasikan: 31 Juli 2020

\begin{abstract}
ABSTRAK
Tujuan penelitian ini adalah menganalisis kesalahan mahasiswa dalam menyelesaikan soal cerita pada materi turunan parsial. Soal cerita turunan parsial merupakan soal aplikasi dalam berbagai bidang yang dapat diselesaikan dengan prosedur turunan parsial. Jenis penelitian adalah penelitian deskriptif kualitatif. Penelitian ini dilaksanakan pada Program Studi Pendidikan Matematika FKIP Undana dengan subjek penelitian ini adalah mahasiswa semester III angkatan 2017 sebanyak 37 orang. Instrumen dalam penelitian ini adalah peneliti sendiri serta soal tes turunan parsial dan pedoman wawancara. Analisis data yang digunakan adalah analisis data kualtiatif yang terdiri dari dua jenis yakni analisis data tes tertulis menggunakan tahapan Newman dan analisis data wawancara menggunakan tahapan reduksi data, penyajian data dan penarikan kesimpulan. Hasil penelitian menununjukkan sebagain besar subjek melakukan kesalahan transformasi soal yakni kesalahan dalam membuat model matematis, menentukan rumus, dan mengetahui operasi hitung yang digunakan. Kondisi ini disebabkan karena kurangnya pemahaman dan kemampuan dasar dalam mengaitkan berbagai konsep untuk memudahkan operasi matematika untuk menyelesaikan soal.
\end{abstract}

Kata kunci: kesalahan, soal cerita, tahapan Newman, turunan parsial.

\begin{abstract}
The purpose of this study is to analyze students' errors in solving word problems on partial derivative. Word problem on partial derivative is an application in various fields that can be solved by partial derivative procedures. The type of research is a qualitative descriptive. This research was conducted at the Mathematics Education Study Program of FKIP Undana with the subject of this study being the third semester consisting of 37 people. The instruments in this study were the researchers themselves, partial derivative test questions, and interview guidelines. Analysis of the data used is a qualitative data analysis consisting of two types namely written test data analysis using the Newman procedures and interview data analysis using data reduction stages, data presentation and drawing conclusions. The results of the study show that the majority of subjects made mistakes in the transformation of problems namely errors in making mathematical models, determining formulas, and knowing the calculated operations used. This condition is caused due to lack of understanding and basic ability in linking various concepts to facilitate mathematical operations to solve problems.
\end{abstract}

Keywords: error analysis, Newman procedures, partial derivative, word problem.

\section{Pendahuluan}

Kemampuan mahasiswa menyelesaikan soal matematika, termasuk soal cerita merupakan suatu keharusan sebagai bagian dari aplikasi konsep teoritik yang telah dipelajari. Soal cerita adalah salah satu komponen penting dalam matematika yang melibatkan aplikasi matematika dalam permasalahan pada kehidupan sehari-hari. Soal cerita merupakan soal yang lebih unik dan menantang daripada soal matematika biasa karena dalam menyelesaikan soal cerita mahasiswa dituntut untuk dapat mengkaitkan antara yang diketahui dan tidak diketahui serta menerjemahkan kalimat soal ke dalam kalimat matematika (Ahmad, Tarmizi, dan Nawawi, 2010). Hal ini juga didukung oleh Bates \& Wiest (2004) bahwa soal cerita menyediakan masalah yang menantang mahasiswa untuk mengaplikasikan kemampuan berpikir matematis dalam berbagai situasi dan merupakan suatu alat yang efisien untuk mengkaitkan kemampuan berpikir matematis dalam kehidupan sehari-hari. Menurut Tello (2010) soal cerita berguna untuk menguji pemahaman mahasiswa karena saat menyelesaikan soal cerita mahasiswa dituntut untuk dapat menggunakan informasi yang terdapat pada soal untuk menentukan strategi yang tepat dalam menemukan 


\section{Range: Jurnal Pendidikan Matematika Vol. 2 No. 1 Tahun 2020 Elisa Novalinda Mata Ratu, dkk}

solusi. Sejalan dengan itu, Prakitipong dan Nakamura (2006) berpendapat bahwa dalam menyelesaikan soal cerita seseorang harus menginterprestasikan maksud soal dalam kalimat matematika sebelum mengaplikasikan proses matematis untuk menemukan jawaban yang tepat. Soal cerita matematika memberikan tantangan bagia siswa untuk mengaplikasikan berpikir matematika dalam berbagai situasi (Sahendra, Budiarto, \& Fuad, 2018).

Berhadapan dengan soal cerita, biasanya membuat mahasiswa mengalami hambatan atau kebingungan apalagi untuk materi tingkat tinggi. Seperti pada materi aplikasi turunan parsial yang mana konten tersebut merupakan domain fungsi dua variabel bebas atau lebih sehingga membutuhkan kemampuan dasar kalkulus yang baik serta kemampuan menganalisis situasi sesuai konteks pertanyaan yang diberikan. Kesulitan yang dialami mahasiswa secara umum adalah kurang pahamnya situasi kontekstual yang disajikan, kerumitan konsep materi sehingga mahasiswa tidak mampu menentukan langkah penyelesaian dengan benar.

Ketidakmampuan menyelesaikan soal cerita turunan parsial ini dapat terlihat jelas dari banyaknya kesalahan yang dibuat mahasiswa baik dalam memahami konteks soal maupun algoritma atau prosedur tehnis turunan. Secara spesifik kesalahan-kesalahan tersebut harus diidentifikasikan secara komprehensif agar dalam pembelajaran turunan parsial, pengajar dapat memfokuskan pada tindakan untuk mereduksi terjadinya kesalahan serupa. Penelusuran kesalah siswa secara spesifik dapat menggunakan prosedur Newman yakni: (1) kesalahan membaca (reading) yaitu ketika mahasiswa bisa membaca soal tetapi salah memahami makna kalimat soal, (2) kesalahan memahami (comprehension), yaitu ketika mahasiswa tidak memahami apa yang diketahui dan apa yang ditanya dari soal yang diberikan, (3) kesalahan transformasi (transformation), yaitu ketika mahasiswa tidak dapat menentukan konsep matematis, rumus, operasi, ataupun prosedur yang dapat digunakan untuk menemukan solusi, (4) kesalahan proses (process skill) yaitu ketika mahasiswa tidak melakukan proses menemukan solusi dengan benar, (5) kesalahan penulisan jawaban (encoding) yaitu ketika mahasiswa tidak dapat merepresentasikan jawaban dengan tepat.

Analisis kesalahan mahasiswa dalam mengerjakan soal cerita berdasarkan prosedur Newman ini menujukkan adanya sebuah evaluasi yang lengkap karena dimulai dari bagaimana mahasiswa membaca soal hingga kemampuan representasi hasil aljabarnya dengan konteks real yang disajikan pada soal. Analisis ini menjadi suatu tujuan yang penting untuk perbaikan proses pembelajaran yang mendukung keterampilan berpikir mahasiswa. Di samping itu mahasiswa akhirnya mendapatkan gambaran tentang tahapan prosedur pemecahan yang telah dan belum dijalankan dan dapat menjadi acuan perbaikan diri secara mandiri.

\section{Metode Penelitian}

Jenis penelitian yang digunakan adalah penelitian deskriptif kualitatif. Penelitian ini akan dilaksanakan di Universitas Nusa Cendana, Fakultas Keguruan dan Ilmu Pendidikan, Program Studi pendidikan matematika dan waktu penelitian dilaksanakan pada bulan Januari 2019 pada semester ganjil tahun ajaran 2018/2019. Subyek penelitian ini adalah mahasiswa semester III sebanyak 37 orang. Instrumen utama dalam penelitian ini adalah peneliti sendiri dengan instrumen bantu yakni soal tes kemampuan matematika, soal tes turunan parsial dan pedoman wawancara. Analisis data yang digunakan adalah analisis data kualtiatif yang terdiri dari dua jenis yakni analisis data tes tertulis menggunakan tahapan Newman dan analisis data wawancara menggunakan tahapan yang dikemukakan Miles dan Huberman (1992) yakni reduksi data, penyajian data dan penarikan kesimpulan. Tahapan analisis data menggunakan tahapan Newman disajikan pada tabel 1 berikut: 


\section{Range: Jurnal Pendidikan Matematika Vol. 2 No. 1 Tahun 2020 Elisa Novalinda Mata Ratu, dkk}

Tabel 1. Analisis Data Tertulis

\begin{tabular}{|c|c|c|}
\hline $\begin{array}{l}\text { Tahapan } \\
\text { Newman }\end{array}$ & Kategori & Deskripsi \\
\hline \multirow[t]{3}{*}{$\begin{array}{l}\text { Membaca } \\
\text { (Reading) }\end{array}$} & Baik & $\begin{array}{l}\text { Mampu memahami makna kata, simbol atau istilah dan dapat } \\
\text { menentukan kata kunci dalam soal. }\end{array}$ \\
\hline & Cukup & $\begin{array}{l}\text { Mampu memahami makna kata, simbol atau istilah dan dapat } \\
\text { menentukan kata kunci dalam soal namun masih terdapat } \\
\text { kesalahan dan kurang lengkap }\end{array}$ \\
\hline & Kurang & Tidak mampu mehami makna kalimat soal. \\
\hline \multirow[t]{3}{*}{$\begin{array}{c}\text { Memahami } \\
\text { (Comprehension) }\end{array}$} & Baik & $\begin{array}{l}\text { Mampu menyebutkan semua yang diketahui dan ditanyakan } \\
\text { atau dapat menentukan cara penyelesaian untuk masalah yang } \\
\text { ditanya dengan benar }\end{array}$ \\
\hline & Cukup & $\begin{array}{l}\text { Mampu menyebutkan apa yang diketahui dan ditanyakan atau } \\
\text { dapat menentukan cara penyelesaian untuk masalah yang } \\
\text { ditanya namun masih terdapat kesalahan dan kurang lengkap }\end{array}$ \\
\hline & Kurang & Tidak ada pengerjaan \\
\hline \multirow[t]{3}{*}{$\begin{array}{c}\text { Transformasi } \\
\text { (Transformation) }\end{array}$} & Baik & $\begin{array}{l}\text { Mampu membuat model matematis, menentukan rumus, dan } \\
\text { mengetahui operasi hitung yang digunakan dengan benar }\end{array}$ \\
\hline & Cukup & $\begin{array}{l}\text { Mampu membuat model matematis, menentukan rumus, dan } \\
\text { mengetahui operasi hitung yang akan digunakan namun masih } \\
\text { terdapat kesalahan atau kurang lengkap }\end{array}$ \\
\hline & Kurang & $\begin{array}{l}\text { Tidak mampu menentukan model, rumus, dan operasi yang } \\
\text { digunakan. }\end{array}$ \\
\hline \multirow[t]{3}{*}{$\begin{array}{l}\text { Keterampilan } \\
\text { (Process Skills) }\end{array}$} & Baik & $\begin{array}{l}\text { Dapat menentukan dan menerapkan prosedur atau langkah } \\
\text { dalam menyelesaikan soal dengan benar atau tanpa kesalahan }\end{array}$ \\
\hline & Cukup & $\begin{array}{l}\text { Dapat menentukan dan menerapkan sebagian atau seluruh } \\
\text { langkah penyelesaian namun masih terdapat kesalahan atau } \\
\text { kurang lengkap }\end{array}$ \\
\hline & Kurang & $\begin{array}{l}\text { Dapat menyelesaikan sebagian atau seluruh langkah } \\
\text { penyelesaian namun masih sangat banyak kesalahan dan } \\
\text { mendapatkan hasil yang salah }\end{array}$ \\
\hline \multirow{3}{*}{$\begin{array}{l}\text { Penulisan } \\
\text { Jawaban } \\
\text { (Enconding) }\end{array}$} & Baik & $\begin{array}{l}\text { Dapat menentukan hasil akhir penyelesaian dan dapat } \\
\text { menuliskan kesimpulan sesuai dengan maksud soal. }\end{array}$ \\
\hline & Cukup & $\begin{array}{l}\text { Dapat menentukan hasil akhir penyelesaian dan dapat } \\
\text { menuliskan kesimpulan sesuai dengan maksud soal tetapi tidak } \\
\text { tuntas }\end{array}$ \\
\hline & Kurang & $\begin{array}{l}\text { Tidak dapat menunjukan jawaban akhir dan kesimpulan } \\
\text { maksud soal }\end{array}$ \\
\hline
\end{tabular}

Validasi data dalam penelitian ini menggunakan perpanjangan pengamatan. Perpanjangan pengamatan berarti peneliti kembali ke lapangan, melakukan pengamatan dan wawancara dengan sumber data yang pernah ditemui maupun sumber data yang baru. Sugiyono (2007) menambahkan bahwa perpanjangan pengamatan ini dilakukan untuk mengecek kembali apakah data yang telah diberikan oleh sumber data selama ini merupakan data yang sudah benar atau tidak. Hal ini bertujuan menumbuhkan keakraban (tidak ada jarak lagi, semakin terbuka dan saling mempercayai) antara peneliti dan narasumber sehingga tidak ada yang disembunyikan lagi. 


\section{Hasil Penelitian dan Pembahasan}

\section{Hasil Penelitian}

Instrumen tes dan wawancara yang telah disusun kemudian divalidasi oleh dua orang dosen secara teoritik di mana soal diperiksa dari segi konten, konstruk, dan Bahasa. Hasil validasi soal turunan parsial yang telah dinyatakan layak digunakan disajikan sebagai berikut:

1. Indeks kesejukan angin I adalah suhu yang dirasakan ketika suhu sebenarnya adalah $\mathrm{T}$ dan kecepatan angin adalah $\mathrm{v}$, maka dapat kita tulis $\mathrm{I}(\mathrm{T}, \mathrm{v})$. Tabel nilai berikut adalah kutipan dari tabel yang disusun oleh National Atmospheric dan Oceanic Administration.

\begin{tabular}{|c|c|c|c|c|c|}
\hline $\mathrm{T}$ & 10 & 20 & 30 & 40 & 50 \\
\hline 20 & 18 & 16 & 14 & 13 & 13 \\
\hline 16 & 14 & 11 & 9 & 7 & 7 \\
\hline 12 & 9 & 5 & 3 & 1 & 0 \\
\hline 8 & 5 & 0 & -3 & -5 & -6 \\
\hline
\end{tabular}

Gunakan tabel di atas untuk menemukan pendekatan linear pada fungsi indeks kesejukan angin ketika T mendekati $16^{\circ} \mathrm{C}$ dan v mendekati $30 \mathrm{~km} / \mathrm{h}$. Kemudian perkirakan indeks kesejukan angin ketika suhu $14^{\circ} \mathrm{C}$ dan kecepatan angin $27 \mathrm{~km} / \mathrm{h}$.

2. Tegangan $V$ dalam rangkaian sederhana perlahan menurun saat baterai habis. Resistensi $R$ perlahan meningkat ketika resistor memanas. Gunakan hukum ohm $V=I R$, untuk menemukan bagaimana arus $I$ saat ini berubah ketika $R=400 \Omega, I=0.08 \mathrm{~A}, \quad d V / d t=-0.01 \mathrm{~V} / \mathrm{s}$ dan $d R / d t=0.03 \Omega / s$

3. Tekanan $1 \mathrm{~mol}$ gas ideal meningkat sebesar $0.05 \mathrm{kPa} / \mathrm{s}$ dan suhu meningkat sebesar $0.15 \mathrm{~K} / \mathrm{s}$. Gunakan persamaan $P V=8.31 T$ untuk menemukan laju perubahan dari volume ketika tekanan $20 \mathrm{kPa}$ dan suhu $320 \mathrm{~K}$

Hasil tes tertulis dianalisis dengan analisis data kualitatif berdasarkan tahapan Newman. Hal ini bertujuan untuk mendapatkan gambaran kemampuan subjek dalam menyelesaikan soal cerita untuk setiap tahapan Newman. Kemampuan ini dikategorikan dalam tiga kategori yakni baik, cukup, dan kurang yang mana dalam analisis kesalahan lebih lanjut difokuskan pada subjek yang berada dalam kategori cukup dan kurang untuk setiap item soal. Kategorisasi kualitatif kesalahan yang dilakukan subjek berdasarkan analisis data tertulis terhadap ketiga butir soal yang diberikan yang hasilnya disajikan pada tabel 2 berikut:

Tabel 2. Rekapitulasi Kategori Kemampuan Penyelesaian Soal

\begin{tabular}{|c|c|c|c|c|}
\hline \multirow{2}{*}{ Tahapan Newman } & \multirow{2}{*}{ Kategori } & \multicolumn{3}{|c|}{ Jumlah Subjek } \\
\cline { 2 - 5 } & & Soal 1 & Soal 2 & Soal 3 \\
\hline \multirow{2}{*}{ Membaca (Reading) } & Baik & 35 & 32 & 31 \\
\cline { 2 - 5 } & Cukup & 0 & 0 & 0 \\
\cline { 2 - 5 } & Kurang & 0 & 0 & 0 \\
\hline Memahami (Comprehension) & Baik & 27 & 20 & 20 \\
\cline { 2 - 5 } & Cukup & 0 & 1 & 2 \\
\cline { 2 - 5 } & Kurang & 8 & 11 & 9 \\
\hline Transformasi (Transformation) & Baik & 20 & 16 & 11 \\
\hline
\end{tabular}


Range: Jurnal Pendidikan Matematika Vol. 2 No. 1 Tahun 2020 Elisa Novalinda Mata Ratu, dkk

\begin{tabular}{|c|c|c|c|c|}
\hline \multirow{2}{*}{ Tahapan Newman } & \multirow{2}{*}{ Kategori } & \multicolumn{3}{|c|}{ Jumlah Subjek } \\
\cline { 2 - 5 } & & Soal 1 & Soal 2 & Soal 3 \\
\cline { 2 - 5 } & Cukup & 6 & 2 & 5 \\
\cline { 2 - 5 } & Kurang & 9 & 14 & 17 \\
\hline Keterampilan Proses (Process & Baik & 15 & 13 & 11 \\
\cline { 2 - 5 } Skills) & Cukup & 12 & 11 & 11 \\
\cline { 2 - 5 } & Kurang & 7 & 8 & 14 \\
\hline Penulisan Jawaban (Enconding) & Baik & 15 & 12 & 10 \\
\cline { 2 - 5 } & Cukup & 10 & 10 & 9 \\
\cline { 2 - 5 } & Kurang & 2 & 3 & 5 \\
\hline
\end{tabular}

Tabel 2 di atas, secara spesifik telah memberikan gambaran banyaknya kategori cukup dan kurang terdapat pada tahapan transformasi yakni kesalahan transformasi yakni subjek tidak dapat menentukan konsep matematis, rumus, operasi, ataupun prosedur yang dapat digunakan untuk menemukan solusi dan keterampilan proses yakni kesalahan dalammenentukan dan menerapkan prosedur atau langkah dalam menyelesaikan soal. Rekapitulasi kesalahan siswa disajikan pada tabel 3 berikut:

Tabel 3. Rekapitulasi kesalahan subjek

\begin{tabular}{|l|c|c|c|c|}
\hline \multirow{2}{*}{ Tipe Kesalahan } & \multicolumn{3}{|c|}{ Nomor Butir Tes } & \multirow{2}{*}{ Total } \\
\cline { 2 - 4 } \cline { 2 - 4 } & $\mathbf{1}$ & $\mathbf{2}$ & $\mathbf{3}$ & \\
\hline Membaca (Reading) & 0 & 0 & 0 & $\mathbf{0}$ \\
\hline Memahami (Comprehension) & 8 & 11 & 9 & $\mathbf{2 8}$ \\
\hline Transformasi (Transformation) & 9 & 14 & 17 & $\mathbf{4 0}$ \\
\hline Keterampilan Proses (Process Skill) & 7 & 8 & 14 & $\mathbf{2 9}$ \\
\hline Menuliskan jawaban (Encoding) & 2 & 3 & 5 & $\mathbf{1 0}$ \\
\hline Total & $\mathbf{3 1}$ & $\mathbf{4 0}$ & $\mathbf{5 0}$ & \\
\hline
\end{tabular}

Berdasarkan tabel 2, kesalahan yang paling umum terjadi adalah kesalahan transformasi. Dilihat dari tiap butir soal, pada nomor 1 terdapat 9 subjek melakukan kesalahan transformasi, nomor 2 terdapat 14 siswa melakukan kesalahan transformasi, dan pada nomor 3 terdapat 17 siswa melakukan kesalahan transformasi. Terdapat cukup banyak variasi kesalahan yang dilakukan subjek serta tidak semua subjek mengerjakan tesnya karena ketika gagal dalam membaca soal maka subjek tidak melanjutkan pekerjaannya. Dari 37 subjek, yang mengerjakan nomor 1 hingga selesai sebanyak 35 subjek dengan 2 subjek tidak mengerjakan soalnya. Pada soal nomor 2, terdapat 30 subjek yang mengerjakan soalnya hingga selesai dengan 5 subjek tidak mengerjakan soalnya, sedangkan pada soal nomor 3, sebanyak 28 subjek mengerjakan hingga selesai dengan 6 siswa tidak mengerjakan soalnya. Untuk analisis lebih lanjut, butir soal yang tidak dikerjakan subjek tidak diikutkan dalam analisis karena kondisi tersebut tidak masuk dalam bagian kesalahan.

Deeskripsi jenis kesalahan subjek dalam menyelesaikan soal cerita turunan parsial disajikan sebagai berikut:

\section{Kesalahan Membaca (Reading Error)}

Dalam menyelesaikan soal cerita turunan parsial, tidak ada subjek yang melakukan kesalahan membaca yakni memahami makna kata, simbol atau istilah dan dapat menentukan kata kunci dalam soal.

\section{Kesalahan Memahami (Comprehension Error)}

Dalam menyelesaikan soal cerita turunan parsial, beberapa subjek yang melakukan kesalahan memahami soal yakni kesalahan dalam menyebutkan/menuliskan semua yang diketahui dan ditanyakan atau dapat menentukan cara penyelesaian untuk masalah yang ditanya. Penyelesaian soal tidak memgharuskan subjek untuk menulisakan diketahi, ditanya, dan dijawab, namun sebagain besar subjek menuliskannya. Salah satu kesalahan memahami disajikan pada gambar 1 berikut: 


\section{Range: Jurnal Pendidikan Matematika Vol. 2 No. 1 Tahun 2020 Elisa Novalinda Mata Ratu, dkk}

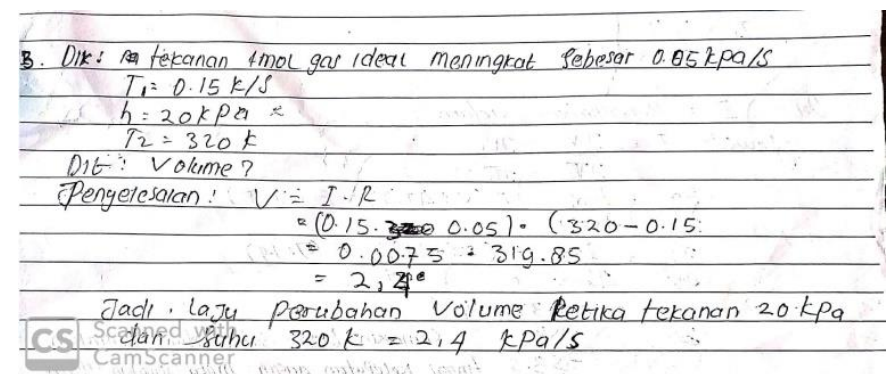

Gambar 1. Jenis kesalahan memahami subjek

Gambar 1 di atas menunjukkan subjek mampu membaca dan memahami informasi yang diketahui dan ditanyakan hanya saja masih terdapat kesalahan dimana subjek tersebut salah dalam menuliskan simbol dari informasi yang terdapat pada soal. Pada soal terdapat informasi $1 \mathrm{~mol}$ gas ideal meningkat sebesar $0.05 \mathrm{kPa} / \mathrm{s}$ dan suhu meningkat sebesar $0.15 \mathrm{~K} / \mathrm{s}$, subjek memisalkan peningkatan $0,05 \mathrm{kPa} / \mathrm{s}$ dengan $\mathrm{T}_{1}$ dan peningkatan sebesar $0.15 \mathrm{~K} / \mathrm{s}$ sebagai $\mathrm{T}_{2}$, padahal peningkatan tekanan dan suhu tersebut merupakan laju perubahan terhadap waktu sehingga harus dituliskan dalam notasi turunan $\mathrm{dP} / \mathrm{dt}=0,05 \mathrm{kPa} / \mathrm{s} \mathrm{dan}$ $\mathrm{dT} / \mathrm{dt}=0,15 \mathrm{~K} / \mathrm{s}$. Dalam kegiatan wawancara, subjek mengungkapkan ketidaktahuannya mengenai notasi turunan yang merepresentasikan kata peningkatan sehingga dimunculkan sebuah notasi yang mewakili informasi itu.

\section{Kesalahan Transformasi (Transformation Error)}

Dalam menyelesaikan soal cerita turunan parsial, banyak subjek yang melakukan kesalahan transformasi soal yakni kesalahan dalam membuat model matematis, menentukan rumus, dan mengetahui operasi hitung yang digunakan. Umumnya subjek dapat menuliskan kembali informasi pada soal dengan benar namun dalam penulisan rumus, persamaan, atau model masih terdapat kesalahan. Salah satu kesalahan transformasi disajikan pada gambar 2 berikut:

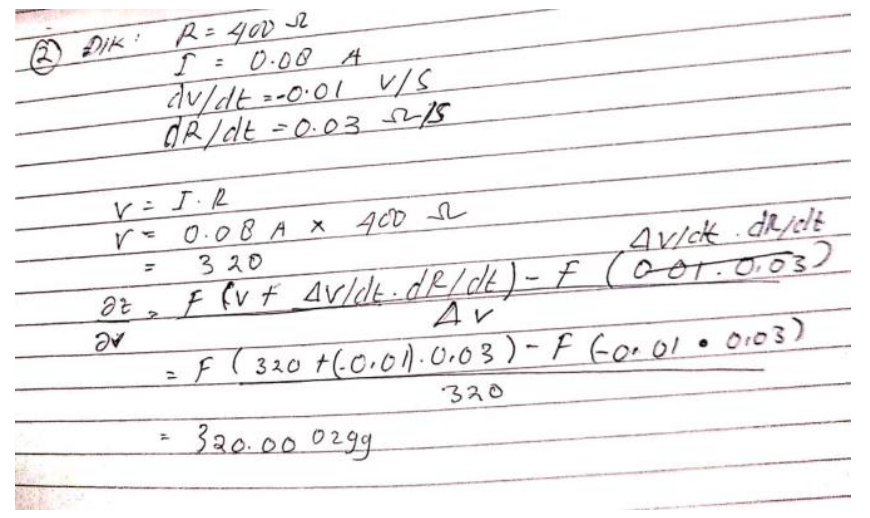

Gambar 2. Jenis kesalahan transformasi subjek

Gambar 2 di atas menunjukkan, subjek tidak mampu menuliskan atau menentukan model, rumus, dan operasi yang digunakan untuk menyelesaikan soal tersebut. Subjek menuliskan turunan pertama dt/dv yang seharusnya menggunakan aturan perkalian dua fungsi di mana $\mathrm{V}=\mathrm{I}$. $\mathrm{R}$ merupakan dua variabel sehingga turunan pertama diperoleh dengan perkalian dua fungsi.

\section{Kesalahan Proses (Process skill Error)}

Dalam menyelesaikan soal cerita turunan parsial, cukup banyak subjek yang melakukan kesalahan proses soal yakni kesalahan dalam menentukan dan menerapkan prosedur atau langkah dalam menyelesaikan soal. Kesalahan umum subjek dalam tahapan ini adalah kesalahan dalam proses perhitungan sehingga 


\section{Range: Jurnal Pendidikan Matematika Vol. 2 No. 1 Tahun 2020 Elisa Novalinda Mata Ratu, dkk}

menghasilkan solusi yang tidak akurat dan kesalahan yang mengakibatkan tidak mampunya subjek melanjutkan proses pengerjaan. Salah satu kesalahan transformasi disajikan pada gambar 3 berikut:

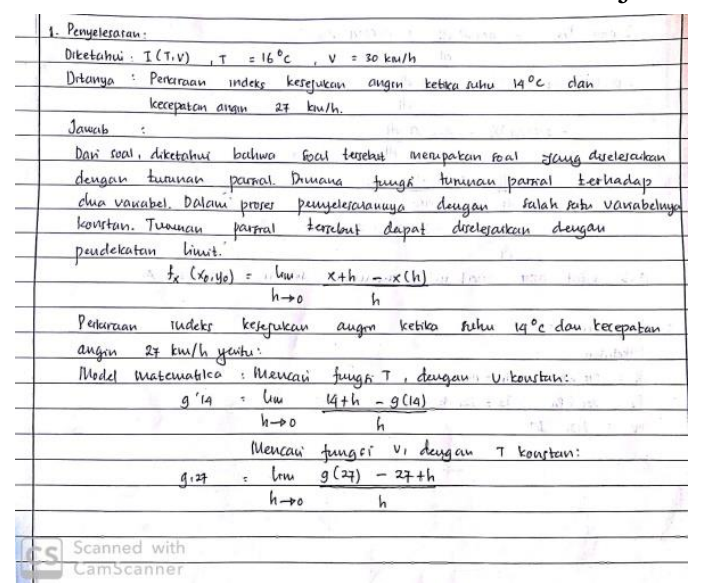

Gambar 3. Jenis kesalahan proses subjek

Gambar 3 di atas menunjukkan, subjek tidak mampu melanjutkan langkah pengerjaannya hingga mendapatkan solusi. Subjek melakukan kesalahan dengan menuliskan secara langsung perkirakan indeks kesejukan angin ketika suhu $14^{\circ} \mathrm{C}$ dan kecepatan angin $27 \mathrm{~km} / \mathrm{h}$ yang sejatinya perkiraan itu harus diperoleh dengan menggunakan turunan di sekitar titik T mendekati $16^{\circ} \mathrm{C}$ dan $\mathrm{v}$ mendekati $30 \mathrm{~km} / \mathrm{h}$ yang ada pada tabel.

\section{Kesalahan Menuliskan Jawaban (Encoding Error)}

Dalam menyelesaikan soal cerita turunan parsial, kesalahan umum yang terjadi pada tahapan ini adalah subjek mempertahankan hasil aljabar sebagai output dari proses perhitungan menggunakan algoritma turunan. Nyatanya soal yang disajikan merupakan soal aplikasi sehingga solusi harus dikembalikan pada konteks soal sehingga bisa dilanjutkan dengan evaluasi logis atau tidaknya solusi yang dihasilkan. Salah satu kesalahan menuliskan jawaban disajikan pada gambar 4 berikut:

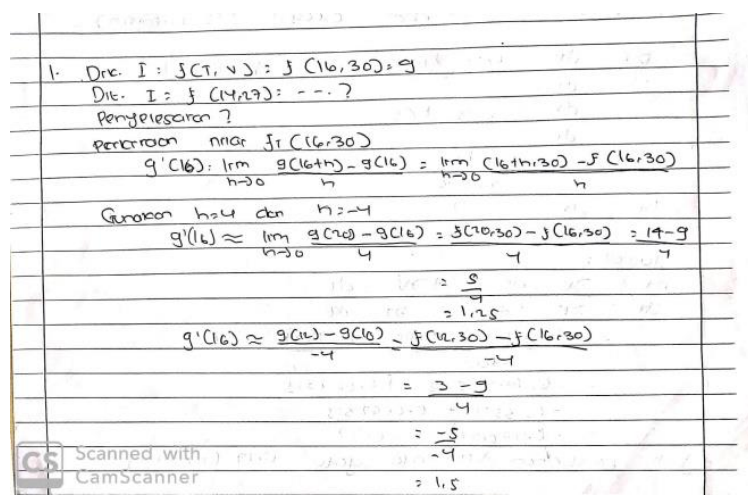

Gambar 4. Jenis kesalahan menuliskan jawaban subjek

Gambar 4 di atas adalah penyelesaian soal nomor 1 dari salah satu subjek. Secara prosedur subjek dikategorikan memiliki kemampuan baik berdasarkan tahapan Newman atau tidak mengalami kesalahan berdasarkan tahapan sebelumnya namun mengalami kesalahan di tahap akhir yakni menuliskan jawaban. Kesalahan ini bukan menunjukan jawaban yang salah namun menunjukan ketidaksingkronan antara jawaban yang dihasilkan secara prokedural dan konteks soal. Subjek menuliskan g'(16) =1,5 yang secara matematis benar namun tidak dinyatakan atau dikembalikan sesuai konteks soal. 


\section{Pembahasan}

Hasil penelitian menunjukan bahwa kesalahan umum subjek melakukan kesalahan transformasi yakni sebuah jenis kesalahan dalam memformulasikan soal ke dalam model matematika untuk diselesaikan. Model matematika adalah jembatan dari situasi real ke matematika yang mana melalui model matematika, situasi real dapat diselesaikan dengan prosedur matematis. Menurut Confrey \& Maloney (2007) pemodelan menghasilkan model yang merupakan deskripsi atau representasi situasi, yang diambil dari disiplin matematika, dalam kaitannya dengan pengalaman seseorang, yang dengan sendirinya telah berubah melalui proses pemodelan. Lebih lanjut Marion \& Lawson (2008) mengungkapkan model menggambarkan keyakinan tentang situasi real ke dalam bahasa matematika. Kesalahan pada tahapan ini memiliki dampak besar karena pengetahuan dasar yang dimiliki serta pemahaman terhadap soal cerita yang ada menjadi tidak bermakna. Pemodelan matematika adalah seni menerjemahkan masalah dari area aplikasi ke formulasi matematika yang dapat ditelusuri yang analisis teoretis dan numeriknya memberikan wawasan, jawaban, dan panduan yang berguna untuk aplikasi yang berasal (Neumaier, 2004).

Kesalahan dalam pemodelan banyak disebabkan oleh kurangnya keterampilan untuk mengaitkan berbagai konsep yang telah dipelajari sebelumnya. Menurut Zulkarnaen (2018) Kesulitan siswa dalam menyelesaikan tugas pemodelan matematika menyebabkan jawaban yang salah. Kesalahan ini disebabkan oleh kebingungan konsep dan prosedur, kelalaian kondisi formula dan fakta yang diberikan; kurangnya pemahaman konsep, dan ketidakmampuan untuk mengubah masalah; ada juga faktor psikologis, seperti kecemasan dan stress. Kompleksitas kegiatan memodelkan dapat dipahami sebagai sebuah kesulitan yang berujung kesalahan karena pemodelan menuntut secara kognitif beberapa kompetensi yang terlibat, termasuk yang non-matematika, pengetahuan ekstra-matematika, pengetahuan matematika itu sendiri dan, khususnya untuk terjemahan ide-ide konseptual (Blum, 2015). Meskipun pada level Newman, kemampuan memodelkan merupakan tahapan yang ada setelah memahami namun posisinya ini tidak menjadikannya memiliki peran yang kecil karena pemodelan membutuhkan aktivitas kognitif tinggi karena menggambungkan berbagai konsep dasar dan teori sebelumnya.

Hasil penelitian ini selaras dengan penelitian Sumule, Amin, dan Fuad (2018) jenis kesalahan yang siswa lakukan adalah kesalahan pemahaman dan transformasi. Alasannya adalah siswa tidak dapat mengidentifikasi kata kunci dalam pertanyaan, menuliskan apa yang diketahui atau diberikan, menentukan formula atau perangkat rencana. Hal senada juga disampaikan oleh Zamzam \& Patricia (2018) yang menyatakan bahwa sering terjadi kesalahan dalam tahap transformasi dan proses keterampilan, hal ini menyebabkan siswa tidak memahami prosedur yang akan digunakan untuk menyelesaikan masalah materi yang tidak dipahami dengan baik.

\section{Kesimpulan}

Beradasarkan temuan penelitian dan pembahasan di atas, dapat disimpulkan bahwa berdasarkan tahapan Newman untuk mengekplorasi kesalahan mahasiswa dalam menyelesaikan soal cerita turunan parsial, subjek cenderung melakukan kesalahan transformasi yakni sebuah jenis kesalahan dalam dalam memformulasikan soal ke dalam model matematika untuk diselesaikan. Kondisi ini disbabkan karena kurangnya pemahaman dan kemampuan dasar dalam mengaitkan berbagai konsep untuk memudahkan operasi matematika untuk menyelesaikan soal.

Temuan penelitian ini memberikan rekomendasi kepada pengajar bahwa proses modeling menjadi bagian yang penting untuk diperhatikan dalam kegiatan pembelajaran. Pembelajaran harus memfokuskan pada prosedur membangun model matematika dengan mengaitkan berbagai konsep dasar yang telah dipelajari. Temuan penelitian ini juga memberikan rekomendasi penelitian lebih lanjut untuk mengekplorasi lebih jauh kesalahan serupa pada kegiatan pemecahan masalah subjek baik siswa maupun mahasiswa sehingga gambaran kesalahan tersebut dapat menjadi acuan perbaika kegiatan pembelajaran. 


\section{Ucapan Terima Kasih}

Terima kasih kepada mahasiswa angkatan 2017 Pendidikan Matematika FKIP Undana yang telah meluangkan waktu membantu peneliti sehingga penelitian ini dapat terselesaikan dengan baik.

\section{Daftar Pustaka}

Ahmad A., Tarmizi, R.A., Nanawi, M. (2010). Visual representasions in mathematical word problem solving among form four student in malacca. Procedia social and behavioral science, 8 (pp.356361)

Bates, E.T, Weist, L.R.2004. Impact of personalization of mathematical word problems student performance. The mathematics Educator, 14(2), (pp.17-26).

Blum W. (2015) Quality Teaching of Mathematical Modelling: What Do We Know, What Can We Do?. In: Cho S. (eds). The Proceedings of the 12th International Congress on Mathematical Education. Springer, Cham. Doi: https://doi.org/10.1007/978-3-319-12688-3_9

Confrey, J., \& Maloney, A. (2007). A theory of mathematical modelling in technological settings. In W. Blum, P. Galbraith, H.W. Henn, \& M. Niss (Eds.), Modelling and applications in mathematics education: The 14th ICMI Study (pp. 57-68). New York, NY: Springer.

Daniel Lawson and Glenn Marion. 2008. An Introduction to Mathematical Modelling. (online) (https://people.maths.bris.ac.uk/ madjl/course_text.pdf), diakses 20 januari 2019

Neumaier, A. (2004). Mathematical Model Building, Chapter 3 in: Modeling Languages in Mathematical Optimization (J. Kallrath, ed.), Applied Optimization, Vol. 88, Kluwer, Boston.

Prakitipong, N. dan Nakamura, S. (2006). Analysis of Mathematics Performance of Grade Five Students in Thailand Using Newman Procedure. Journal of International Cooperation in Education, 9(1), (pp.111-122).

Sahendra, A., Budiarto, M. T., \& Fuad, Y. (2018). Students' Representation in Mathematical Word ProblemSolving: Exploring Students' Self-efficacy. IOP Conf. Series: Journal of Physics: Conf. Series 947 (2018) 012059 doi :10.1088/1742-6596/947/1/012059

Sumule, U., Amin, S. M., \& Fuad, Y. (2018). Error Analysis of Indonesian Junior High School Student in Solving Space and Shape Content PISA Problem Using Newman Procedure. IOP Conf. Series: Journal of Physics: Conf. Series 947 (2018) 012053 doi :10.1088/1742-6596/947/1/012053.

Tello, E.A. 2010. Making Mathematics Word Reliable Measures of Student Mathematics Abilities. Journal of Mathematics Education, 3 (1), (pp.15-26).

Zamzam, K. F. \& Patricia, F. A. (2018). Error Analysis of Newman to Solve the Geometry Problem in Terms of Cognitive Style. Advances in Social Science, Education and Humanities Research (ASSEHR), volume 160 University of Muhammadiyah Malang's 1st International Conference of Mathematics Education (INCOMED 2017). (24-27), Malang: Universitas Muhamamadiyah.

Zulkarnaen, R. (2018). Why is mathematical modeling so difficult for students? AIP Conference Proceedings 2021, 060026 (2018); https://doi.org/10.1063/1.5062790 Published Online: 17 October 2018 (1-6) 